\title{
Zawodówka (nie) jest OK? Szkoły zawodowe (branżowe) w opiniach uczniów a wybory edukacyjno-zawodowe w odniesieniu do sytuacji na rynku pracy
}

\section{KEYWORDS}

planning for the future of vocational education, vocational counseling, labor market, youth, vocational education

\begin{abstract}
Kozielska Joanna, Zawodówka (nie) jest OK? Szkoły zawodowe (branżowe) w opiniach uczniów a wybory edukacyjno-zawodowe $w$ odniesieniu do sytuacji na rynku pracy [Vocational school is (not) OK? Vocational school in middle school students' opinions vs. educational-vocational choices with regard to the situation on the labour market]. Kultura - Społeczeństwo - Edukacja nr 1(13) 2018, Poznań 2018, pp. 201-211, Adam Mickiewicz University Press. ISSN 2300-0422. DOI 10.14746/kse.2018.13.15.
\end{abstract}

The proposed text is an illustration of selected conclusions from a four-module research project conducted in one of the Wielkopolska counties. The aim of the empirical verification was to: make the educational and professional characteristics of the junior high school plans, get acquainted with the opinions of the employers on the situation in the local labor market, get acquainted with the plans connected with the employment of employees, get acquainted with the preparation of graduates of particular types of schools to meet the opinion of the directors of post-gymnasium schools on the state of the vocational education and to get acquainted with the opinions of the students of the upper secondary school classes on the situation on the labor market, the offer of vocational education and the self-assessment of preparation to enter the labor market. The research was conducted in the first quarter of 2016 and 2017, by the diagnostic survey method. The article is based on one of the study modules - a study of middle school students that was conducted in 2016 - the findings from the 2017 study will be cited in some places 
for comparative purposes only. Due to the specificity of the research topic, the selection of the research sample was random. High school students $(N=486$ in 2016 and $N=490$ in 2017), upper secondary school students $(N=503-2016$ and $N=498-2017)$, upper secondary school graduates ( $N=6$ in 2016 and 2017 ) and the largest employers ( $N=78$ in 2016, $N=102$ in 2017). In this project the diagnostic survey method was used as the basis. The method used to analyze the contents was made using the local traditional (printed) and internet press and the thematic work edited by the County Labor Office in Gniezno and other institutions.

The main topic of this paper was the educational and vocational elections of junior high school students in the context of the situation on the local labor market (which, as it turns out, does not correspond to its needs), revealing weaknesses in vocational counseling. Regarding the specific nature of the region, attention has also been paid to the face (as opposed to the offer) of vocational education (depicted in the vocational school 2017/2018) depreciated in the eyes of the local community, which in the reality of the local labor market seems to be a rational educational choice without causing closure Road to higher education. The dissertation on vocational education has been made an additional element of publication.

\section{Edukacyjne wybory młodzieży}

Specyficzne i nieustannie zmieniające się warunki przestrzeni społeczno-kulturowej, a wraz z nimi „wydłużenie okresu przygotowania do udziału w społeczności dorosłych (moratorium - już nie dziecko ale jeszcze nie dorosły)" (Krzychała, 2007: 8), spowodowały, iż zrodziła się „nowa faza życia i nowa przestrzeń społeczna”. Tak właśnie „narodził się fenomen młodzieży” (Krzychała, 2007: 8). Ta kategoria osób znajduje się na etapie rozwoju, który związany jest z podejmowaniem decyzji dotyczących własnej przyszłości. Warto podkreślić, iż

kształtowanie relacji partnerskich i rodzinnych oraz modelownie kariery społeczno-zawodowej jest obecnie otwartym zadaniem na całe życie, poddawane ciągłym zmianom i przedefiniowaniom. To oczywiste, a nawet wręcz banalne stwierdzenie dla nas, uczestników społeczeństwa uczącego się (całe życie). Nauka i praca są zasadniczymi elementami, poprzez które konstruuje się społeczny profil biografii i dokonuje się wejście młodzieży w zróżnicowane tory życia zawodowego charakteryzujące drogi życiowe dorosłych. (Piorunek, 2004b: 27) 
Poniżej zaprezentowane zostaną wnioski z badań, których respondentami uczyniono młodzież zamieszkującą powiat gnieźnieński ${ }^{1}$.

W badaniu gimnazjalistów ostatnich klas (próbę badawczą stanowiło 256 uczennic i 230 uczniów) największą aktywnością wykazali się uczniowie z gimnazjów w Gnieźnie. Aktywność związana z wypełnieniem kwestionariusza ankiety przez resztę gimnazjalistów z powiatu była niska. Zdecydowana większość $(68,30 \%)$ biorących udział w badaniu to zatem mieszkańcy miasta, tylko co trzeci mieszka na wsi $(31,70 \%)$. Struktura wykształcenia rodziców respondentów jest bardzo zróżnicowana, blisko $60 \%(57,60 \%)$ ojców to absolwenci zasadniczych szkół zawodowych i techników, wyższe wykształcenie zdobyło 16,00\% ojców. Jeśli chodzi natomiast o wykształcenie matek - grupa absolwentek zasadniczych szkół zawodowych także utrzymuje się na wysokim poziomie (co trzecia matka). Blisko $10 \%$ więcej matek niż ojców legitymuje się natomiast wyższym wykształceniem (25,00\%). Co piąty gimnazjalista nie wie, jaką szkołę ukończyli jego rodzice, co budzić powinno obawy. Wiedza na temat wykształcenia rodziców to jeden z pierwszych etapów doradztwa zawodowego - preorientacji zawodowej, rozbudzenie ciekawości poznawczej dotyczącej życia zawodowego i edukacyjnych wyborów najbliższych - nie tylko rodziców, ale i dziadków, rodzeństwa itd.

Uczniowie stanowiący grono respondentów uzyskali zróżnicowane średnie ocen. Najwięcej z nich (prawie 20\%) to osoby, które w semestrze zimowym roku szkolnego 2015/2016 osiągnęły średnią ocen między 3,5 a 4,0, niemalże równoliczne grupy stanowią osoby ze średnią 3,00-3,50 oraz 4,0 i 4,5 (po ok. 17\%). Co piąty uczeń osiągnął średnią 4,50-5,00. 3,00\% badanych nie wie, czy będzie kontynuować naukę lub nie zamierza kontynuować dalszej edukacji, natomiast blisko 97,00\% respondentów z relacjonowanej próby badawczej zamierza kształcić się dalej. Ich plany w momencie pomiaru były w zasadzie sprecyzowane. (Badania przeprowadzono w ostatniej klasie szkoły gimnazjalnej na pół roku przed zakończeniem roku szkolnego). Największym zainteresowaniem przyszłych absolwentów szkół gimnazjalnych cieszyły się licea ogólnokształcące.

${ }^{1}$ Autorskie badania przeprowadzono w latach 2016-2017 w powiecie gnieźnieńskim, wykorzystując metodę sondażu diagnostycznego (kwestionariusz ankiety). Projekt badawczy składał się z czterech modułów, stanowiących odrębne kategorie prób badawczych: I. Uczniowie szkoły gimnazjalnej (ostatnia klasa), II. Uczniowie szkoły ponadgimnazjalnej (technika, zasadnicze szkoły zawodowe), III. Pracodawcy, IV. Dyrektorzy i grono pedagogiczne szkół ponadgimnazjalnych (technika, zasadnicze szkoły zawodowe). Rozstrzygano między innymi następujące kwestie: I. Jakie plany edukacyjno-zawodowe mają gimnazjaliści z powiatu gnieźnieńskiego? Czym warunkowane są ich wybory? II. Jak przedstawia się sytuacja na lokalnym rynku pracy? Jaki profil pracownika jest najbardziej poszukiwany przez pracodawców? Jak postrzega się kształcenie zawodowe/szkolnictwo zawodowe? 


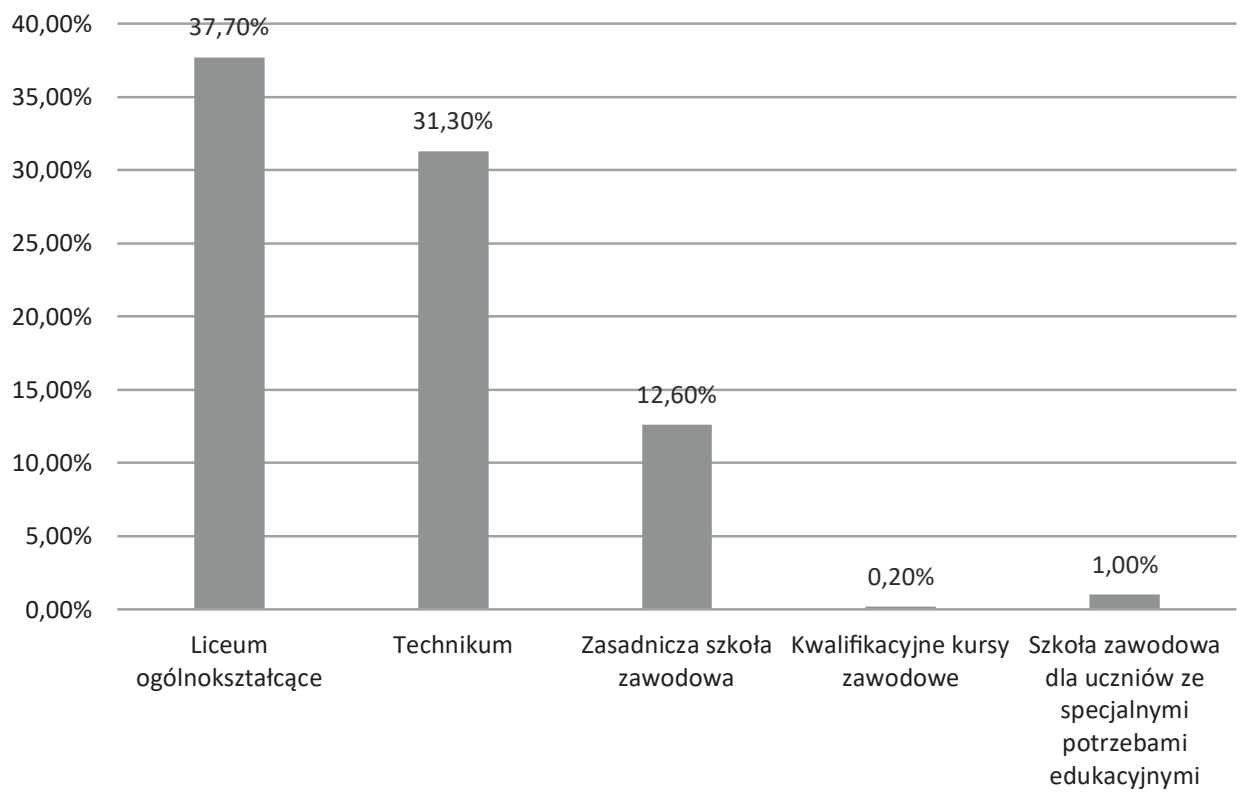

Ryc. 1. Plany edukacyjne uczniów

Źródło: opracowanie własne

Ponad 50,00\% uczniów deklaruje, iż zna ofertę szkolnictwa ponadgimnazjalnego, ale potrzebuje wsparcia informacyjnego w zakresie oferty edukacyjnej w powiecie gnieźnieńskim. Co dziesiąty stwierdza, że nie ma żadnej wiedzy na temat oferty edukacyjno-zawodowej w mieście i powiecie, 37,40\% deklaruje, że ma pełną wiedzę na temat oferty. Co ciekawe, nawet nie znając oferty, deklarują, co zaprezentowano powyżej, że już wybrali przyszłą szkołę. Prezentowane badanie przeprowadzono pół roku przed możliwością dokonania autentycznego wyboru kolejnego szczebla kształcenia. Po zestawieniu badań z lutego i danych Starostwa Powiatowego w Gnieźnie ( $\mathrm{N}=1216$ wszyscy gimnazjaliści powiatu) z danymi z rekrutacji (lipiec) okazało się, że (prognozowane) wybory (będące tematem relacjonowanego projektu) pokryły się (w sensie popularności poszczególnych typów szkół) z realnymi wyborami absolwentów gimnazjów. Na liceum ogólnokształcące zdecydowało się 43,00\% uczniów, szeregi uczniów techników zasiliło 37,00\% absolwentów gimnazjum, do szkół zawodowych trafiło 20,00\% uczniów. Deklaracje z lutego spowodowały jednak, iż władze powiatu ograniczyły liczbę oddziałów w liceach ogólnokształcących. W deklaracjach z lutego blisko 40,00\% gimnazjalistów planowało wybrać liceum ogólnokształcące, choć co dziesiąty nie zdecydował jeszcze, w jakim typie klasy chce się kształcić (wśród pozostałych największym 
powodzeniem cieszyły się klasy humanistyczne i o profilu obronnym). Co trzeci badany zamierzał kontynuować naukę w technikum, a tylko co dziesiąty w zasadniczej szkole zawodowej. Co znamienne, uczniowie decydują się na liceum ogólnokształcące niezależnie od średnich uzyskiwanych ocen.

Uczniowie, którzy deklarują, że naukę kontynuować będą w szkołach zawodowych i technikach, w zdecydowanej większości przypadków (72,00\%) potrafili wskazać i nazwać zawód, który wybrali, ale byli i tacy (38,00\%), którzy wskazywali na takie, których nie można zdobyć w wymienionych szkołach: psycholog, terapeuta, lekarz, nauczyciel, kryminolog, prawnik, komentator sportowy itp. Zdecydowana większość z nich (wybierających ZSZ) $(64,00 \%)$ nie potrafiła także wskazać, jakie predyspozycje są potrzebne do tego, by wykonywać wybrany przez nich zawód. Ponad 62,00\% uczniów nie potrafiło też określić, na jakie zawody jest dziś na rynku pracy (choćby lokalnym) zapotrzebowanie. Decydują zatem w zasadzie „W ciemno".

Po roku trwania programu "Zawodówka jest OK”, którego beneficjentami uczyniono rodziców i uczniów, a w ramach którego w powiecie doradcy zawodowi i pracodawcy promowali szkolnictwo zawodowe, trend uległ zmianie: $42,50 \%$ uczniów zadeklarowało wybór technikum, 37,50\% liceum ogólnokształcącego a 20,00\% szkoły branżowej I stopnia (od roku szkolnego 2017/2018 nowa nazwa szkoły zawodowej). Badaną grupę charakteryzował niski poziom deklaracji związanej z mobilnością w celu podjęcia kształcenia czy pracy. 88,00\% uczniów zdeklarowało, iż uczyć się chce „na miejscu”, co w przypadku badanych oznaczało w Gnieźnie, tylko co dziesiąty przewiduje możliwość wyjazdu do innego miasta (np. oddalonego o $50 \mathrm{~km}$ Poznania z bogatszą ofertą edukacyjną).

\section{Specyfika lokalnego rynku pracy}

Gimnazjaliści dokonali wyboru na zasadzie „chybił - trafił” - jak zadeklarowali - bez znajomości potrzeb lokalnego i regionalnego (nie mówiąc o regionalnym, ogólnopolskim) rynku pracy i swoich predyspozycji i zainteresowań zawodowych, co obnaża po raz kolejny słabą kondycję doradztwa zawodowego - pierwszy jego moduł dotyczy bowiem poznawania siebie, drugi - lokalnej/regionalnej oferty edukacyjnej oraz specyfiki lokalnego/regionalnego rynku pracy.

Wykaz branż zidentyfikowanych jako branże o największym potencjale rozwojowym i/lub branż strategicznych dla województwa wielkopolskiego oraz barometr zawodów i specjalności wskazuje na poziomie regionu 44 zawody deficytowe. Wśród nich przeważają te, których podjęcie wiąże się z wymogiem 
posiadania wykształcenia zawodowego (24 zawody). Zawody wskazane jako deficytowe na obszarze powiatu gnieźnieńskiego i szerzej dla regionu to m.in: administratorzy systemów komputerowych, analitycy, testerzy i operatorzy systemów teleinformatycznych, betoniarze i zbrojarze, blacharze samochodowi, cieśle i stolarze budowlani, dekarze i blacharze budowlani, doradcy finansowi i inwestycyjni, elektromechanicy i elektromonterzy, fryzjerzy, graficy komputerowi, hydraulicy, inżynierowie mechanicy, kelnerzy i barmani, kierowcy ciągnika siodłowego, krawcy i pracownicy produkcji odzieży, kucharze, lakiernicy samochodowi, malarze budowlani, mechanicy maszyn i urządzeń, mechanicy pojazdów samochodowych, monterzy instalacji budowlanych, murarze, nauczyciele praktycznej nauki zawodu, nauczyciele przedmiotów zawodowych, obuwnicy, opiekunowie osoby starszej lub niepełnosprawnej, pielęgniarki, pomoce kuchenne, posadzkarze, pracownicy ds. rachunkowości i księgowości, robotnicy budowlani, robotnicy obróbki drewna i stolarze, rolnicy i hodowcy, samodzielni księgowi, spawacze metodą MIG/MAG, spawacze metodą TIG, specjaliści automatyki i robotyki, specjaliści ds. organizacji produkcji, szefowie kuchni, tapicerzy, technicy elektrycy, technicy mechanicy, tynkarze. Do zdecydowanej większości zawodów wskazanych jako deficytowe przygotowują zasadnicze szkoły zawodowe (od roku szkolnego 2017/2018 szkoły branżowe I i II stopnia) i technika. Lokalni pracodawcy deklarują, iż najczęściej poszukiwanymi przez nich pracownikami są absolwenci techników $(100,00 \%)$ dalej zasadniczych szkół zawodowych $(60,00 \%)$ i politechnik (40,00\%), aż 80,00\% pracodawców deklaruje, iż przy dużej aktywności w poszukiwaniu pracownika (internetowe ogłoszenia wraz z ogłoszeniami w lokalnej prasie i mediach, nabory wewnętrzne, współpracą z urzędem pracy, agencjami pośrednictwa pracy i samymi szkołami) ma bardzo duże problemy ze znalezieniem pracownika, odpowiadającego profilem zawodowym potrzebom firmy.

\section{Zdeprecjonowane szkolnictwo zawodowe}

Zdeprecjonowanie szkolnictwa zawodowego powoduje, iż nie cieszy się ono popularnością wśród młodzieży. Wybór szkoły zawodowej to wybór negatywny, często poprzedzony niepowodzeniami szkolnymi.

Asocjacje na temat szkół technicznych są bardziej pozytywne. Technika kojarzą się gimnazjalistom $\mathrm{z}$ faktem, iż po ich ukończeniu zdobędą zarówno zawód, jak i maturę. Młodzież zaznacza: „możemy, ale nie musimy iść na studia, bo mamy już wykształcenie zawodowe” "można zdawać maturę i ma się tytuł 
technika”, „jest dobre kiedy chcesz mieć i zawód i wyższe wykształcenie”, „mogę studiować i jestem ukierunkowany na dany zawód”. Najwięcej pejoratywnych skojarzeń zebrała zasadnicza szkoła zawodowa. Respondenci uznali, iż to szkoła dla mało ambitnych, że po szkole zawodowej nie ma się pracy albo pracuje się za „marne grosze”.

Za egzemplifikację niech posłużą wypowiedzi respondentów:

zawodówka kojarzy mi się źle, zawsze mnie przed nią rodzice ostrzegali, a nawet $w$ sumie straszyli, że jak się nie będę uczyła, to tam trafię i będę miała ciężkie życie. $(\mathrm{K} / 2016 / 12)$

Do zety trafiaja same matoły, które sobie $w$ nauce nie radza, bo tam jest najnizszy poziom i tylko tam sobie poradza (...). (K/2016/77)

Zawsze wiedziałam, że pójdę do liceum i na studia, w ogóle nie myślałam o zawodówce, jak jadę autobusem, to widuję chłopaków z „zetki”, jak sprzątaja przy szkole $w$ takich kombinezonach niebieskich, ja bym tak nie chciała, wole się uczyć niż pracować póki co (...) po studiach będę miała lepsza pracę i większe pieniądze. $(\mathrm{K} / 2016 / 16)$

Do szkoły zawodowej trafiaja gorsi uczniowie, którzy sobie nie radzą, potem maja problem z praca, mało zarabiaja (...). (M/2016/23)

Szkoła zawodowa kojarzy mi się z ciężka praca, brudem za paznokciami i pijanymi facetami na budowie... wolę pójść do liceum, tam czeka mnie lepsza przyszłość. (K/2016/107)

Szkoła zawodowa kojarzy mi sięźle, po niej nie ma się dobrej pracy, dziś trzeba się uczyć, studia robić, żeby znaleźć pracę. (M/2016/65)

Zawodówka kojarzy mi się ze słabymi uczniami, którzy sobie by nigdzie indziej nie poradzili, kojarzy mi się raczej z chłopakami niż dziewczynami, z takimi nieciekawymi zawodami, ciężka praca fizyczna na budowach. Z brudnymi kamizelkami (...). (K/2016/54)

To szkoła dla leniwych analfabetów, mam takich $w$ klasie... nic z nich nie będzie, tylko do „z” się nadaja, a może nawet i nie. (K/2016/17)

Ja bym się tam wstydziła chodzić, wiadomo, że tam sa najgorsi uczniowie. $(\mathrm{K} / 2016 / 54)$

Znalazło się tylko kilka pozytywnych głosów związanych z faktem, iż wyposaża w konkretny zawód i od razu można zacząć pracę. 
Zawodówki nie sa takie złe, mam koleżankę, jest młoda, a już ma swój zakład fryzjerski i świetnie sobie radzi, jej koleżanki się ucza i nie maja nic, a ona super sobie radzi i dobrze żyje, stać ją na wszystko, jest samodzielna (...). (K/2016/77)

Fajnie bo można od razu mieć pracę, zarabiać własne pieniądze, a przecież można dalej też się uczyć. (M/2016/76)

To dobre szkoly dla tych, którzy np. maja rodzinny biznes, mam kolegę, którego rodzice mają cukiernię no i wiadomo, że on tam idzie (do szkoły zawodowej), żeby móc to przejać od rodziców swoich. (M./2016/12)

Moja mama skończyła zawodówkę, ma swoją pracownię krawiecka, nigdy nie narzeka, mówi, że robi to, co lubi, pracuje na siebie, także no fajnie dobrze mi się kojarzy, a ojciec pracuje w magazynie, ciężko ma, ale mówi, że za biurkiem by nie usiedział, też skończył zawodówkę, mówi, że ta szkoła życia go nauczyła (...). (M/2016/34)

Jak wspomniano powyżej, szkoła zawodowa kojarzy się ze słabym uczniem, natomiast S. Kwiatkowski zwraca uwagę, że jest ona trudna, ponieważ jej uczeń oprócz wiedzy teoretycznej, deklaratywnej, zdobywa także wiedzę praktyczną (por. Kwiatkowski, 2001).

Rynek pracy powiatu gnieźnieńskiego, co wskazano powyżej, to rynek wykazujący się deficytem w zakresie specjalistów z branż, do których przygotowuje szkolnictwo zawodowe i techniczne. Oferta edukacyjna szkół ponadgimnazjalnych niezmiennie od kilku lat nie jest adekwatna (choć jest bardzo bogata) do potrzeb kadrowych pracodawców, analiza oferty edukacyjnej szkół pozwala stwierdzić, iż w powiecie można się kształcić w blisko 60 zawodach, wśród których zidentyfikowano wszystkie wskazane powyżej jako deficytowe. Wnioski płynące z badań przeprowadzonych wśród pracodawców wskazują jednak, iż często zawód mieści się w kategorii zawodu deficytowego (np. spawacz, monter automatyki), jednakże nieadekwatny program kształcenia, przestarzałe urządzenia dostępne w niedoposażonych szkołach powodują, iż absolwent nie wpisuje się w profil poszukiwanego do pracy kandydata, nie jest $\mathrm{w}$ stanie sprostać wymaganiom pracodawcy (brakuje mu wiedzy, kompetencji, umiejętności). Ponadto pracodawcy w swojej pracy wykorzystują najnowsze technologie, których, jak deklarują w badaniach dyrektorzy szkół, na próżno szukać w ich placówkach edukacyjnych. Także nauczyciele, w związku z powyższym, są niekompetentni w zakresie nowoczesnych technologii. Ogromnym problemem jest pozyskanie nauczycieli praktycznej nauki zawodu. Niedofinansowane szkolnictwo zawodowe skutkuje obniżeniem jakości 
kształcenia. 80,00\% ankietowanych pracodawców stwierdziło, iż można wprawdzie znaleźć pracownika, ale trudno o kogoś z odpowiednim wykształceniem i kwalifikacjami, a sytuację poprawiłyby, jak deklarują: wdrożenie właściwego systemu kształcenia uwzględniającego potrzeby rynku, program staży i praktyk poprawiający kompetencje przyszłego absolwenta, program dodatkowych szkoleń, wyposażenie pracowni szkolnych w sprzęt analogiczny do sprzętu pracodawców, targi pracy, wykłady w szkołach, zwiększenie znaczenia i unowocześnienie kształcenia zawodowego - w szkołach powinien znajdować się sprzęt, na którym pracuje się w danym zakładzie pracy, tak by absolwent był w pełni przygotowany do pracy zaraz po zakończeniu edukacji i odbyciu staży/praktyk. Żaden z pracodawców nie określił, iż nie ma trudności w znalezieniu pracownika.

W badanych przedsiębiorstwach największy odsetek zatrudnionych stanowią pracownicy z wykształceniem zasadniczym zawodowym oraz średnim zawodowym. Takie wyniki oznaczają, że większe szanse na lokalnym rynku w powiecie gnieźnieńskim mają przede wszystkim osoby posiadające określone kwalifikacje i kompetencje zawodowe. Oczywiście absolwenci mogą migrować w celu poszukiwania pracy do innych miast, w tym jednak przypomnę, iż respondenci tworzący grupę badawczą nie deklarują chęci migracji.

\section{Podsumowanie}

Wybory edukacyjne, a w konsekwencji zawodowe, młodzieży gimnazjalnej z relacjonowanej grupy zdają się być osadzone w strategii stochastycznej oraz asekuracyjnej. Młodzi ludzie w kwestii planowania przyszłości edukacyjno-zawodowej zwykle polegają na opinii innych i aktualnych trendach, niewpisujących się w obraz potrzeb lokalnego rynek pracy, przez co optymalizacja trendów choćby w lokalnym wymiarze staje się wyzwaniem. Młodzież gimnazjalna $\mathrm{z}$ badanej grupy częściej decyduje się na kontynuowanie nauki w liceach ogólnokształcących niż w szkołach uczących zawodu. Jest to prawdopodobnie wynikiem zdeprecjonowania szkolnictwa zawodowego. Szkolnictwa, którego w opiniach respondentów należy unikać. Sytuacji nie sprzyja także mało widoczna działalność doradców zawodowych. Tworzy się zatem niejako zamknięty krąg: negatywnie kojarząca się szkoła zawodowa - wybory edukacyjno-zawodowe koncentrujące się wokół liceów ogólnokształcących. W tym wszystkim należy uwzględnić jeszcze lokalnych pracodawców, permanentnie poszukujących rąk do pracy (w zawodach, do których przygotowuje szkolnictwo zawodowe). Sytuacja powiatu nie jest odosobniona, wpisuje się w sytuację ogólnopolską, co przedstawia np. raport „Niedobór 
talentów", czyli cykliczne badanie ManpowerGroup, którego celem jest określenie skali problemu, z jakim spotykają się pracodawcy poszukujący pracowników do swoich organizacji. W corocznej ankiecie, która przeprowadzana jest przez ManpowerGroup od 2006 roku na świecie i od 2008 roku w Polsce, bierze udział około 40 tys. respondentów z ponad 40 krajów, w tym 750 z Polski. Odpowiadającymi są osoby odpowiedzialne za politykę personalną w małych, średnich i dużych firmach prywatnych i instytucjach państwowych. 45\% pracodawców w Polsce deklaruje trudności w pozyskaniu pracowników. To najwyższy wynik od ostatnich 6 lat. W zestawieniu globalnym, obejmującym 43 państwa na całym świecie, nasz kraj znalazł się w pierwszej połowie, prześcigając jednocześnie średnią globalną. Na szczycie grup zawodowych obarczonych największym niedoborem talentów uplasowali się wykwalifikowani pracownicy fizyczni, inżynierowie oraz kierowcy. Niezmiennie od kilku kolejnych lat grupą zawodową, której przedstawicieli znaleźć najtrudniej, są wykwalifikowani pracownicy fizyczni. Do puli tej należą m.in. mechanicy, elektrycy, spawacze, monterzy, operatorzy wózków widłowych, murarze, drukarze, stolarze czy tokarze. Na drugim miejscu znaleźli się kierowcy, a zaraz za nimi inżynierowie, którzy zamykają pierwszą trójkę.

Poważnym wyzwaniem dla systemu edukacji jest zatem zreformowanie szkolnictwa zawodowego (czego będziemy w najbliższym czasie świadkami) tak, by stało się dla uczniów stojących przed wyborem szkoły atrakcyjne, by jego absolwent był przygotowany do pracy w środowisku najnowszych technologii. Inną istotną kwestią stać się winno przywrócenie wysokiej rangi szkolnictwu zawodowemu, (od roku szkolnego 2017/2018) branżowemu.

\section{Literatura}

Bauman Z. (2000). Razem osobno. Kraków.

Bauman Z. (2002). Ponowoczesność jako źródło cierpień. Warszawa.

Bauman Z. (2005). Życie na przemiał. Kraków.

Beck U. (2002). Społeczeństwo ryzyka. W drodze do innej nowoczesności. Warszawa.

Giddens A. (2001). Nowoczesność i tożsamość. „Ja” i społeczeństwo w epoce późnej nowoczesności. Warszawa.

Kozielska J. (2014). Poakcesyjne migracje zarobkowe. Kontekst teoretyczno-empiryczny. Wsparcie społeczne. Poznań.

Kozielska J. (2016). Planowanie przyszłości edukacyjno-zawodowej przez młodzież gimnazjalna w kontekście aktualnych potrzeb rynku pracy. „Społeczeństwo i Edukacja” 21(2).

Krzychała S. (2007). Projekt życia. Młodzież w perspektywie badań rekonstrukcyjnych. Wrocław.

Kwiatkowski S.M. (2001). Edukacja zawodowa wobec rynku pracy i integracji europejskiej. Warszawa. 
Młodzi na rynku pracy. Pod lupa; ManpowerGroup, (2014). http://efl.pl/wp content/uploads/2016/08/ EFL_MLODZI_PRACA_RAPORT_www.pdf, dostęp: 12.12.2016.

Piorunek M. (red). (2004a). Młodzież w świecie wspótczesnym. Z badań orientacji biograficznych młodych okresu transformacji. Poznań.

Piorunek M. (2004b). Projektowanie przyszłości edukacyjno-zawodowej w okresie adolescencji. Poznań.

Piorunek M. (2008a). Edukacja i praca w cyklu życia człowieka. [W:] E. Gaweł-Luty, J. Kojkoł (red.). Edukacja wobec tożsamości społecznej. Gdańsk.

Piorunek M. (2008b). Edukacja i praca jako komponenty tożsamości człowieka w przestrzeni postnowoczesności. [W:] J. Modrzewski, M.J. Śmiałek, K. Wojnowski. Relacje podmiotów w lokalnej przestrzeni edukacyjnej. Kalisz-Poznań.

Solarczyk-Ambrozik E. (2004). Kształcenie ustawiczne w perspektywie globalnej i lokalnej. Między wymogami rynku a indywidualnymi strategiami edukacyjnymi. Poznań.

Szaban J. (2013). Rynek pracy w Polsce i Unii Europejskiej. Kraków. 